\title{
Control of $\beta-\mathrm{Si}_{3} \mathrm{~N}_{4}$ Crystal Morphology and Its Mechanism (Part 1) Effect of $\mathrm{SiO}_{2}$ and $\mathrm{Y}_{2} \mathrm{O}_{3}$ Ratio-
}

\author{
Mikito KITAYAMA, Kiyoshi HIRAO, ${ }^{*}$ Motohiro TORIYAMA* and Shuzo KANZAKI* \\ Synergy Ceramics Laboratory, Fine Ceramics Research Association, 1-1, Hirate-cho, Kita-ku, Nagoya-shi 462-8510 \\ *National Industrial Research Institute of Nagoya, 1-1, Hirate-cho, Kita-ku, Nagoya-shi 462-8510
}

\author{
$\boldsymbol{\beta}-\mathrm{Si}_{3} \mathrm{~N}_{4}$ 結晶モフォロジーの制御とそのメカニズム（第 1 報） \\ $-\mathrm{SiO}_{2}$ と $\mathrm{Y}_{2} \mathrm{O}_{3}$ 比の効果— \\ 北山幹人・平尾喜代司 ${ }^{*} \cdot$ 鳥山素弘 $*$. 神崎修三* \\ ファインセラミックス技術研究組合シナジーセラミックス研究所, 462-8510 名古屋市北区平手町 1-1 \\ *名古屋工業技術研究所, 462-8510 名古屋市北区平手町 1-1
}

\begin{abstract}
The effect of $\mathrm{Y}_{2} \mathrm{O}_{3} / \mathrm{SiO}_{2}$ ratio on grain growth of $\mathrm{Si}_{3} \mathrm{~N}_{4}$ was systematically investigated using the "seed" fabrication method. The aspect ratio of $\beta-\mathrm{Si}_{3} \mathrm{~N}_{4}$ crystals heat-treated with an additive composition of $\mathrm{Y}_{2} \mathrm{O}_{3}$ : $\mathrm{SiO}_{2}=1: 2$ was found to be much smaller than that of $\mathrm{Y}_{2} \mathrm{O}_{3}: \mathrm{SiO}_{2}=2: 1$. It was confirmed that this was due to the difference in solubility of $\mathrm{Si}_{3} \mathrm{~N}_{4}$ caused by the change of $\mathrm{Y}_{2} \mathrm{O}_{3} / \mathrm{SiO}_{2}$ ratio of the liquid phase. The number of $\beta$-crystals originally contained in the raw $\mathrm{Si}_{3} \mathrm{~N}_{4}$ powder changed very little in the $\mathrm{Y}_{2} \mathrm{O}_{3}: \mathrm{SiO}_{2}=1$ : 2 composition, while it significantly decreased in the $\mathrm{Y}_{2} \mathrm{O}_{3}: \mathrm{SiO}_{2}=2: 1$ composition, which resulted in a considerable difference in aspect ratio. A mechanism for this enhanced solubility of $\mathrm{Si}_{3} \mathrm{~N}_{4}$ in the liquid phase with high $\mathrm{Y}_{2} \mathrm{O}_{3} / \mathrm{SiO}_{2}$ ratio was proposed.

[Received June 7, 1999; Accepted July 21, 1999]
\end{abstract}

Key-words : Silicon nitride, Morphology, Additive, Seed, Ostwald ripening, Phase transformation

\section{Introduction}

Tailoring microstructure by the addition of a small fraction of larger sized grains with controlled size distributions, often called as the "seed," into finer matrix grains has been proven to significantly improve the mechanical property and thermal conductivity of $\beta-\mathrm{Si}_{3} \mathrm{~N}_{4} \cdot{ }^{1), 2)}$ Hirao et al. developed a systematic method to fabricate high quality rod-like $\beta$ - $\mathrm{Si}_{3} \mathrm{~N}_{4}$ single crystal particles for this purpose. ${ }^{3)}$ In their study, two flux systems were chosen to control the morphologies of crystals: compositions with the molar ratio of $\mathrm{Y}_{2} \mathrm{O}_{3}: \mathrm{SiO}_{2}=1: 2$ and $2: 1$ yielded crystals with average aspect ratios of 4 and 10, respectively. Kanzaki et al. observed that $\mathrm{Si}_{3} \mathrm{~N}_{4}$ powders with small amounts of oxygen content resulted in heterogeneous microstructure containing fine matrix and large grains with high aspect ratio when sintered with $\mathrm{Y}_{2} \mathrm{O}_{3}$ and $\mathrm{Al}_{2} \mathrm{O}_{3}$ additives, while powders with large amounts of oxygen provided a fine and homogeneous microstructure with the same additives. ${ }^{4)}$ Collectively, it is expected that the molar ratio of $\mathrm{Y}_{2} \mathrm{O}_{3}$ and $\mathrm{SiO}_{2}$ would be critical for controlling the morphology of $\beta$ - $\mathrm{Si}_{3} \mathrm{~N}_{4}$ crystal. However, no mechanism was considered to rationalize this effect.

Park et al. demonstrated that the amount of $\mathrm{Yb}_{2} \mathrm{O}_{3}$ additive had a significant effect on grain growth of $\beta$ - $\mathrm{Si}_{3} \mathrm{~N}_{4} \cdot{ }^{5}$ ) They hot-pressed a fine $\alpha-\mathrm{Si}_{3} \mathrm{~N}_{4}$ powder with the addition of 2, 4, 8 and 16 mass\% of $\mathrm{Yb}_{2} \mathrm{O}_{3}$. Resulting microstructures with the addition of 8 and 16 mass $\%$ of $\mathrm{Yb}_{2} \mathrm{O}_{3}$ showed much larger average grain sizes than ones with 2 and 4 mass $\%$. The present author analyzes that 8 mass $\%$ of $\mathrm{Yb}_{2} \mathrm{O}_{3}$ corresponds to the molar ratio of $\mathrm{Yb}_{2} \mathrm{O}_{3}: \mathrm{SiO}_{2}=1: 1.84$ considering the oxygen content in the raw $\mathrm{Si}_{3} \mathrm{~N}_{4}$ powder. Subsequently, Lee et al. gas-pressure-sintered a fine $\alpha$ - $\mathrm{Si}_{3} \mathrm{~N}_{4}$ powder with the addition of the same amounts of $\mathrm{Yb}_{2} \mathrm{O}_{3}{ }^{6}$ ) This time, enhanced grain growth was observed with the $\mathrm{Yb}_{2} \mathrm{O}_{3}$ addition of 16 mass \% corresponding to the molar ratio of $\mathrm{Yb}_{2} \mathrm{O}_{3}: \mathrm{SiO}_{2}=1: 0.84$, however the enhanced vaporization of $\mathrm{Yb}_{2} \mathrm{O}_{3}$ should be taken into accounts at a higher sintering temperature than the previous work. Again, no mechanism was considered to rationalize these results.
Recently a new model for anisotropic Ostwald ripening has been developed, ${ }^{7}$ and extended to the $\alpha-\beta$ transformation. ${ }^{8)}$ Also, the "seed" fabrication process has been proven to be a useful method for investigating grain growth of $\beta-\mathrm{Si}_{3} \mathrm{~N}_{4} \cdot{ }^{9)}$ Combining this experimental method and the model, it has become possible to analyze grain growth of $\mathrm{Si}_{3} \mathrm{~N}_{4}$ quantitatively, and thus, to elucidate the effects of sintering additives on grain growth: what a particular additive really does. The purpose of this paper is to clarify the effect of the $\mathrm{Y}_{2} \mathrm{O}_{3}$ and $\mathrm{SiO}_{2}$ ratio on grain growth of $\mathrm{Si}_{3} \mathrm{~N}_{4}$ using the "seed" fabrication method, and to solve its mechanism referring to the anisotropic Ostwald ripening model.

\section{Experimental}

Powder mixtures of $\alpha$ - $\mathrm{Si}_{3} \mathrm{~N}_{4}$ (E-5 Grade, Ube Industries, Ltd.), $\mathrm{Y}_{2} \mathrm{O}_{3}$ and $\mathrm{SiO}_{2}$ (Hokko Chemicals Ltd.) with the molar ratios of $20: 1: 2$ and $20: 2: 1$, which are respectively called as $(1: 2)$ and $(2: 1)$ later in this work, were planetary milled for $3 \mathrm{~h}$ in a $\mathrm{Si}_{3} \mathrm{~N}_{4}$ jar with $\mathrm{Si}_{3} \mathrm{~N}_{4}$ balls using methanol as a mixing medium. The resulting slurries were dried and passed through a 60-mesh nylon sieve. The powder mixtures were then charged into $\mathrm{BN}$ crucibles in a loose powder state, and heat-treated at 1750, 1800, 1850 and $1900^{\circ} \mathrm{C}$ for $2 \mathrm{~h}$ under a nitrogen pressure of $1 \mathrm{MPa}$. The aggregated porous bodies were lightly crushed using a mortar and pestle, passed through a 100-mesh nylon sieve, and rinsed using $50 \%$ hydrofluoric acid, and then, concentrated sulfuric acid to remove the glassy phase and possible yttrium compounds. ${ }^{3)}$ The $\mathrm{Si}_{3} \mathrm{~N}_{4}$ powders thus obtained were identified their phases using X-ray diffraction (XRD). Small amounts of powders were dispersed in distilled water, and each aliquot was dropped on a scanning electron microscope (SEM) specimen holder. After drying, all rodlike $\beta$ - $\mathrm{Si}_{3} \mathrm{~N}_{4}$ crystals were laid along the surface of a SEM specimen holder, and thus, it was easy to measure their widths and lengths from SEM photographs using a digitizer. At least, 300 of crystals were analyzed for each powder.

Powder mixtures were also hot-pressed in a graphite die 
coated with high purity $\mathrm{BN}$ powder (GP grade, Denki Kagaku Kogyo K.K.) at $1800^{\circ} \mathrm{C}$ for $2 \mathrm{~h}$ under a pressure of $40 \mathrm{MPa}$ in a flowing nitrogen atmosphere, and subsequently annealed at $1850^{\circ} \mathrm{C}$ for $2 \mathrm{~h}$ under a nitrogen pressure of 1 $\mathrm{MPa}$ in a BN crucible filled with the same powder mixtures. Specimens were cut, polished using $1 \mu \mathrm{m}$ diamond slurry, and plasma-etched using $\mathrm{CF}_{4}$ gas for SEM observation. Mean grain sizes were determined using the linear intercept method from SEM photographs. Specimens for the transmission electron microscopy (TEM) were prepared by the standard mechanical thinning method. A $3 \mathrm{~mm}$ disc was cut from each bulk material, mechanically thinned up to $100 \mu \mathrm{m}$, dimpled, and Ar ion-milled (acceleration voltage $4 \mathrm{kV}$, ion beam current $1-2 \mu \mathrm{A}$, beam angle $14^{\circ}$ ) for about $20 \mathrm{~h}$ until a minute hole at the center of disc was observed. Analytical electron microscopy was performed using TEM (JEOL, 2010F) equipped with energy-dispersive X-ray (EDX) spectroscope (Model No. 663D-6SUS, Noran Instruments, Inc., USA). Because it was found that a surface layer of carbon completely masked signals from nitrogen, the specimens were not coated with it. To avoid beam broadening, the thinnest parts in the TEM specimens were selected for EDX chemical analysis. About $30 \mathrm{~s}$ of signals were collected for each analysis.

\section{Results and discussion}

It was found that the powders heat-treated at $1750^{\circ} \mathrm{C}$ for $2 \mathrm{~h}$ contained a negligible amount of $\alpha$-phase and the rests consisted only of $\beta$-phase irrespective of powder compositions. This means that the phase transformation nearly completes at $1750^{\circ} \mathrm{C}$ for $2 \mathrm{~h}$, and grain growth is categorized as Ostwald ripening in the current experimental temperature range. Figure 1 compares mean widths $(W)$, lengths $(L)$ and aspect ratios $(A)$ of $\beta-\mathrm{Si}_{3} \mathrm{~N}_{4}$ crystals heat-treated at temperatures from 1750 to $1900^{\circ} \mathrm{C}$ for $2 \mathrm{~h}$ with two additive compositions, $(1: 2)$ and $(2: 1)$. The mean width of the composition $(2: 1)$ is about twice larger than that of the composition $(1: 2)$. They increase very slowly in both compositions. It should be noted that the mean width of the composition $(1: 2)$ heat-treated at $1900^{\circ} \mathrm{C}$ for $2 \mathrm{~h}$ is still smaller than that of the composition $(2: 1)$ heat-treated at $1750^{\circ} \mathrm{C}$ for $2 \mathrm{~h}$. Mean lengths are much larger than mean widths reflecting the rod-like morphology of $\beta-\mathrm{Si}_{3} \mathrm{~N}_{4}$. The mean length of the composition $(2: 1)$ is much longer than that of the composition $(1: 2)$. As a result, the mean aspect ratio

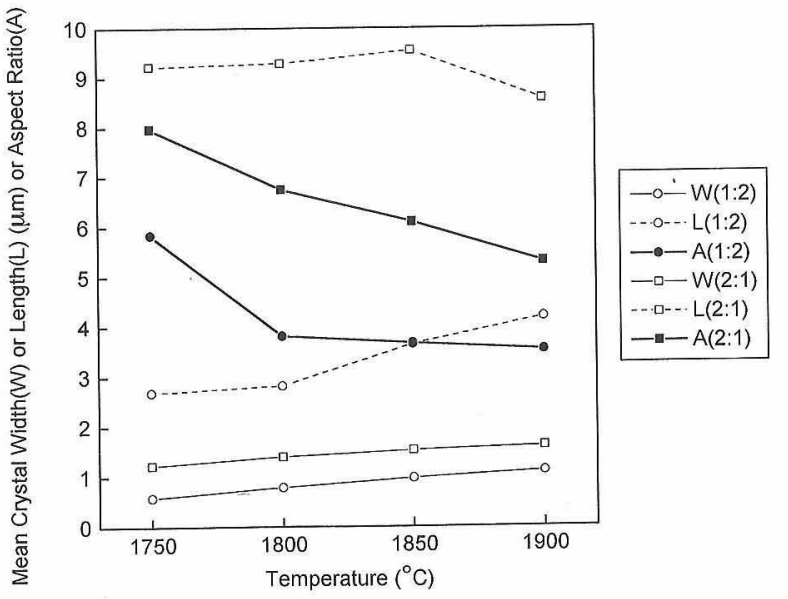

Fig. 1. Mean width $(W)$, lengths $(L)$ and aspect ratios $(A)$ of $\beta$ $\mathrm{Si}_{3} \mathrm{~N}_{4}$ crystals heat-treated at temperatures from 1750 to $1900^{\circ} \mathrm{C}$ for $2 \mathrm{~h}$ with two additive compositions, $\mathrm{Y}_{2} \mathrm{O}_{3}: \mathrm{SiO}_{2}=1: 2$ and $2: 1$, which are designated in each parenthesis as $(1: 2)$ and $(2: 1)$, respectively. of the composition $(2: 1)$ is also much higher than that of the composition $(1: 2)$, even though the mean width of the composition $(2: 1)$ is about twice larger than that of the composition $(1: 2)$. The mean aspect ratios decrease with temperature increase in both compositions as theoretically predicted for the anisotropic Ostwald ripening. ${ }^{7)}$. However, an initial large difference in the mean aspect ratio between both compositions remains at later stages of Ostwald ripening. Figures 2 and 3 show SEM photographs of dispersed $\beta$-Si ${ }_{3} \mathrm{~N}_{4}$ crystals heat-treated at 1750 and $1850^{\circ} \mathrm{C}$, respectively, for $2 \mathrm{~h}$ with additive compositions $(1: 2)$ and $(2: 1)$, which well illustrate the difference in aspect ratio above mentioned. Hirao et al. originally found the difference in aspect ratio between both compositions at $1850^{\circ} \mathrm{C}$. $^{3)}$ It is demonstrated that the difference in aspect ratio has already been occurred at $1750^{\circ} \mathrm{C}$, at which the phase transformation has completed. Figure 4 show SEM photographs of polished and etched surfaces of dense $\beta-\mathrm{Si}_{3} \mathrm{~N}_{4}$ hot-pressed at $1800^{\circ} \mathrm{C}$ for $2 \mathrm{~h}$ and subsequently annealed at $1850^{\circ} \mathrm{C}$ for $2 \mathrm{~h}$ with fluxes of the compositions $(1: 2)$ and $(2: 1)$. When they are compared with Fig. 3 , the difference in aspect ratio is not so obvious mainly due to the incline of elongated $\beta$ $\mathrm{Si}_{3} \mathrm{~N}_{4}$ grains, and probably due to the impingement of elongated grains resulting the suppression of grain growth in the [001] direction. However, a significant difference in grain size is obvious between them demonstrating that the
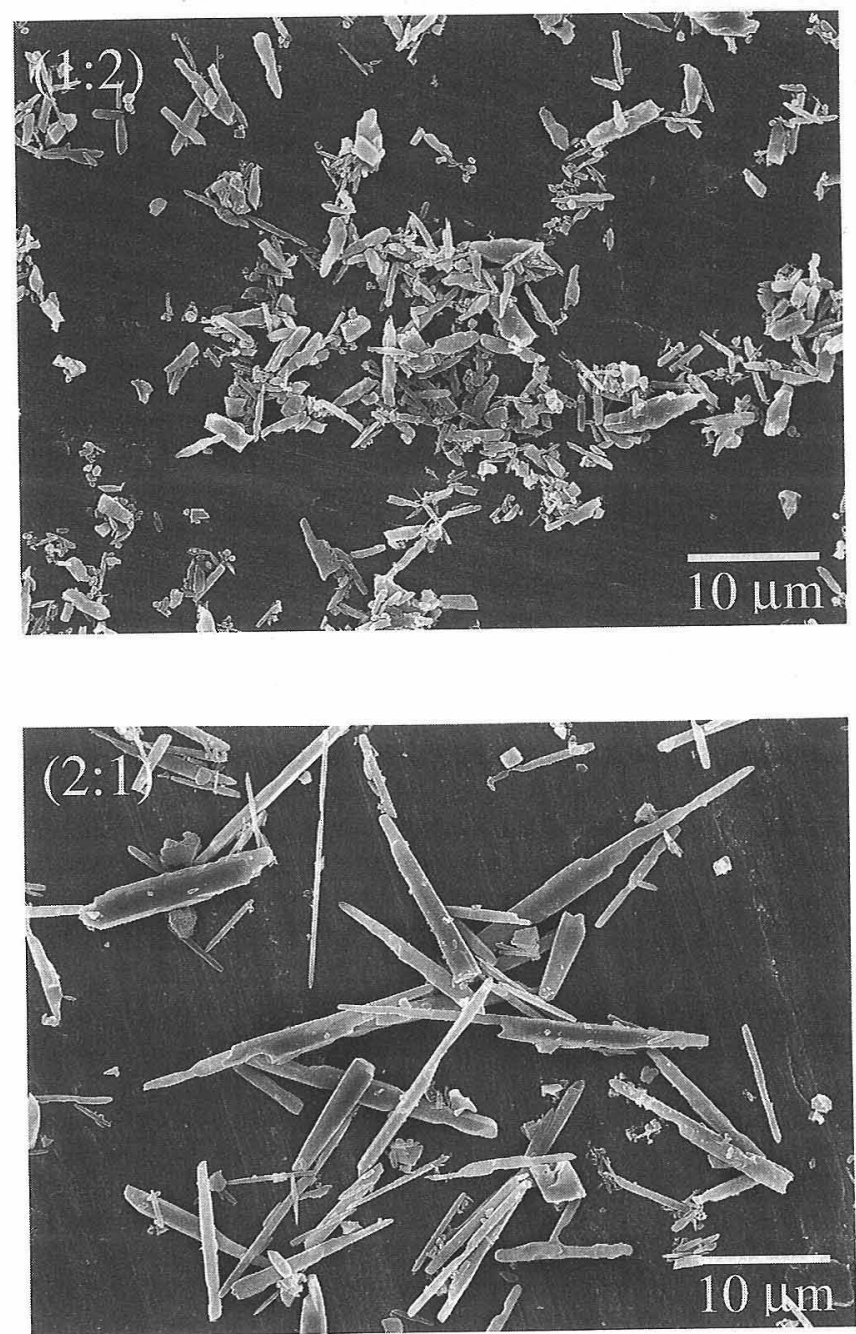

Fig. 2. SEM photographs of dispersed $\beta$ - $\mathrm{Si}_{3} \mathrm{~N}_{4}$ crystals heattreated at $1750^{\circ} \mathrm{C}$ for $2 \mathrm{~h}$ with the additive compositions of $\mathrm{Y}_{2} \mathrm{O}_{3}$ : $\mathrm{SiO}_{2}=1: 2(1: 2)$ and $\mathrm{Y}_{2} \mathrm{O}_{3}: \mathrm{SiO}_{2}=2: 1(2: 1)$. 

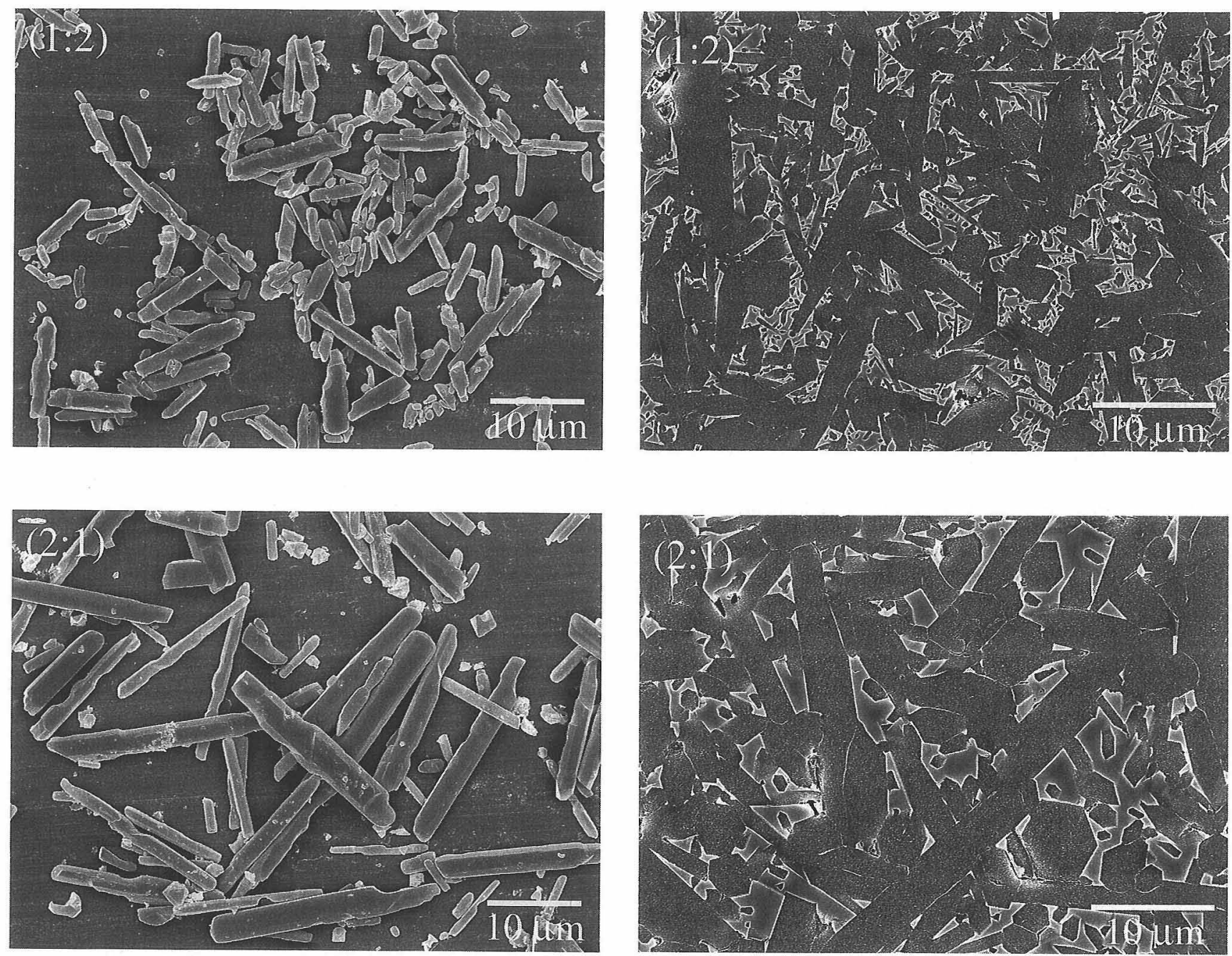

Fig. 3. SEM photographs of dispersed $\beta-\mathrm{Si}_{3} \mathrm{~N}_{4}$ crystals heattreated at $1850^{\circ} \mathrm{C}$ for $2 \mathrm{~h}$ with the additive compositions of $\mathrm{Y}_{2} \mathrm{O}_{3}$ : $\mathrm{SiO}_{2}=1: 2(1: 2)$ and $\mathrm{Y}_{2} \mathrm{O}_{3}: \mathrm{SiO}_{2}=2: 1(2: 1)$.

$\mathrm{Y}_{2} \mathrm{O}_{3} / \mathrm{SiO}_{2}$ ratio influences grain size not only in the loose powder compacts but also in the dense sintered bodies. The number of fine grains is much greater in the composition ( 1 : 2 ) than in the composition $(2: 1)$. As a result, the mean grain sizes are 1.3 and $2.6 \mu \mathrm{m}$ for the compositions $(1: 2)$ and $(2: 1)$, respectively. This result is consistent with the findings by Park et al. ${ }^{5)}$ and Lee et al. ${ }^{6}$ ) that extensive grain growths of $\beta$ - $\mathrm{Si}_{3} \mathrm{~N}_{4}$ were observed when a $\mathrm{Yb}_{2} \mathrm{O}_{3}$ additive exceeded critical amounts. Because the phase diagram of $\mathrm{Si}_{3} \mathrm{~N}_{4}-\mathrm{Y}_{2} \mathrm{O}_{3}-\mathrm{SiO}_{2}$ system is similar to that of $\mathrm{Si}_{3} \mathrm{~N}_{4}-\mathrm{Yb}_{2} \mathrm{O}_{3}-$ $\mathrm{SiO}_{2}$ system, it is expected that their grain growth behaviors are also similar. Thus, it has been confirmed experimentally that the $\mathrm{Y}_{2} \mathrm{O}_{3}$ and $\mathrm{SiO}_{2}$ ratio controls grain growth of $\beta-\mathrm{Si}_{3} \mathrm{~N}_{4}$.

Then, a following question arises: why the $\mathrm{Y}_{2} \mathrm{O}_{3}$ and $\mathrm{SiO}_{2}$ ratio controls grain growth of $\beta-\mathrm{Si}_{3} \mathrm{~N}_{4}$. Figure 5 shows the phase diagram of $\mathrm{Si}_{3} \mathrm{~N}_{4}-\mathrm{Y}_{2} \mathrm{O}_{3}-\mathrm{SiO}_{2}$ system at $1630^{\circ} \mathrm{C}$. ${ }^{10}$ ) The broken line indicate a liquid field at $1730^{\circ} \mathrm{C}$. The corrected $\mathrm{Y}_{2} \mathrm{O}_{3}$ and $\mathrm{SiO}_{2}$ ratios considering both the amount of $\mathrm{SiO}_{2}$ contained in the raw powder and the weight loss during the heat treatment are shown by the arrows for the (1: 2 ) and $(2: 1)$ compositions in this figure. An important aspect drawn from this diagram is that the solubility of $\mathrm{Si}_{3} \mathrm{~N}_{4}$ in the liquid phase with the $(2: 1)$ composition is much larger than that with the $(1: 2)$ composition at both temperatures. To confirm the difference of $\mathrm{Si}_{3} \mathrm{~N}_{4}$ solubility

Fig. 4. SEM photographs of polished and etched surfaces of dense $\beta-\mathrm{Si}_{3} \mathrm{~N}_{4}$ hot-pressed at $1800^{\circ} \mathrm{C}$ for $2 \mathrm{~h}$ and subsequently annealed at $1850^{\circ} \mathrm{C}$ for $2 \mathrm{~h}$ with the additive compositions of $\mathrm{Y}_{2} \mathrm{O}_{3}$ : $\mathrm{SiO}_{2}=1: 2(1: 2)$ and $\mathrm{Y}_{2} \mathrm{O}_{3}: \mathrm{SiO}_{2}=2: 1(2: 1)$.

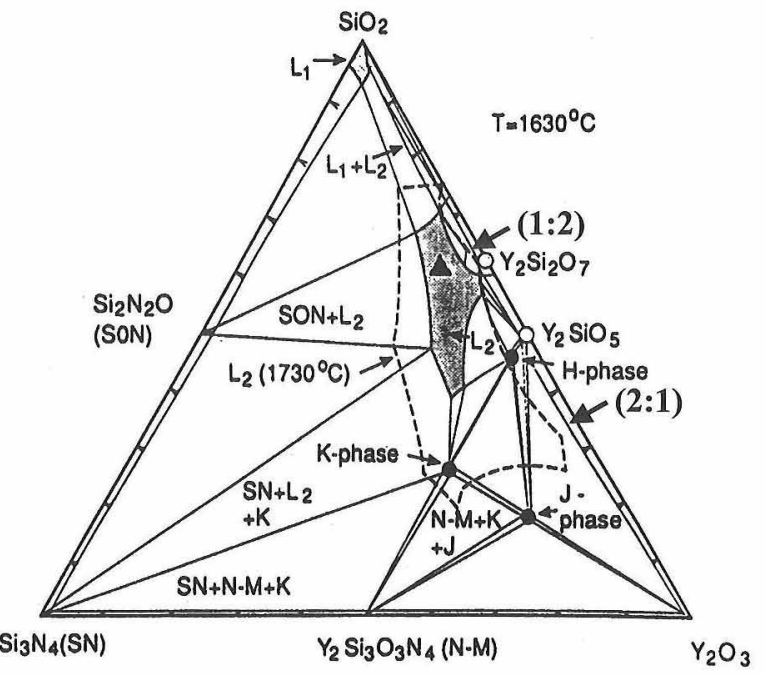

Fig. 5. Phase diagram of $\mathrm{Si}_{3} \mathrm{~N}_{4}-\mathrm{Y}_{2} \mathrm{O}_{3}-\mathrm{SiO}_{2}$ system at $1630^{\circ} \mathrm{C}$. ${ }^{10)}$ The broken line indicates a liquid phase field at $1730^{\circ} \mathrm{C}$. The corrected $\mathrm{Y}_{2} \mathrm{O}_{3}$ and $\mathrm{SiO}_{2}$ ratios considering both the amount of $\mathrm{SiO}_{2}$ contained in the raw powder and the weight loss during the heat treatment are shown by the arrows for the $(1: 2)$ and $(2: 1)$ compositions. 
in the liquid phase between the $(1: 2)$ and $(2: 1)$ compositions, EDX chemical analysis was performed for the grain boundary phases. Figures $6(\mathrm{a}),(\mathrm{b})$ and (c) show representative EDX spectra of $\beta-\mathrm{Si}_{3} \mathrm{~N}_{4}$ grain, the grain boundary glassy phase of the composition ( $1: 2)$, and that of the composition (2:1), respectively. From Fig. 6(a), we can know that the nitrogen peak intensity, $I_{\mathrm{N}}$, is much smaller than the silicon peak intensity, $I_{\mathrm{Si}}$ (about 1/10) due to the atomic number difference. When comparing Figs. 6(b) and (c), we can notice that the peak intensities of silicon and yttrium, $I_{\mathrm{Si}}$ and $I_{\mathrm{Y}}$, reflect the additive compositions: $I_{\mathrm{Si}}>I_{\mathrm{Y}}$ for the composition $(1: 2)$ and vice versa. The most important difference between them is that the weak intensity of nitrogen peak is clearly observed in Fig. 6(c) in contrast with the absence in Fig. 6(b), and that the oxygen peak intensity, $I_{0}$, is smaller in Fig. 6(c) than that in Fig. 6(b) even though the sum of $I_{\mathrm{Si}}$ and $I_{\mathrm{Y}}$ are similar between them. Based on the observation in Fig. 6(a), even the weak intensity of nitrogen peak observed in Fig. 6(c) actually

(a)

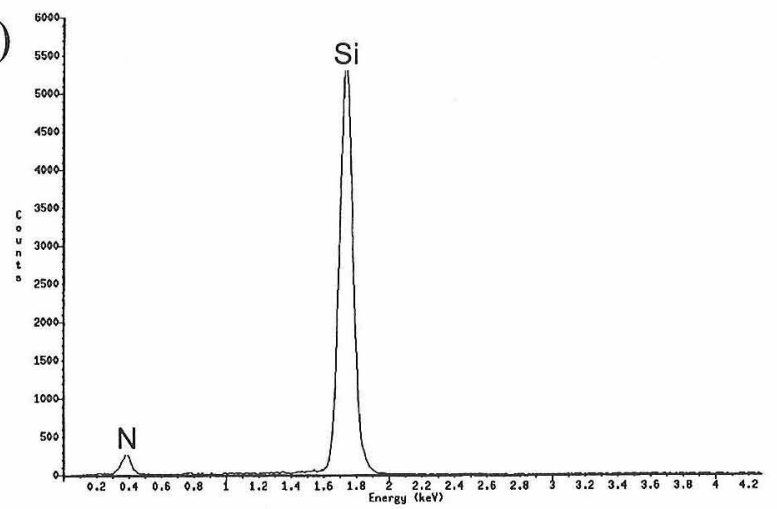

(b)

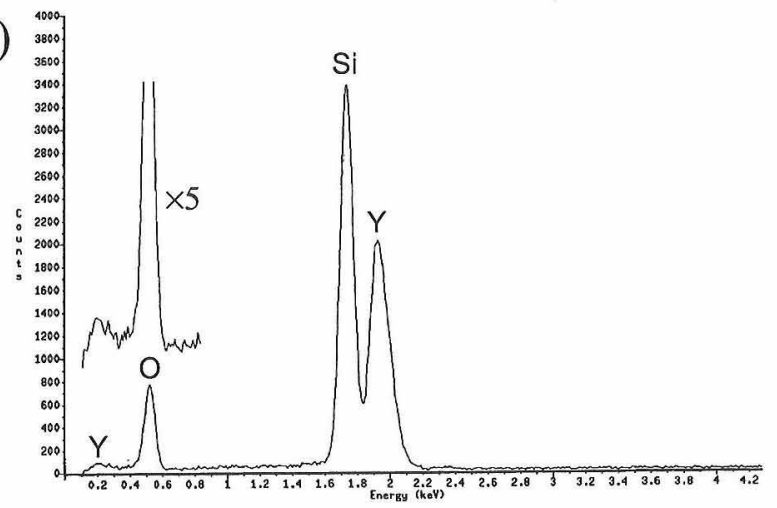

(c)

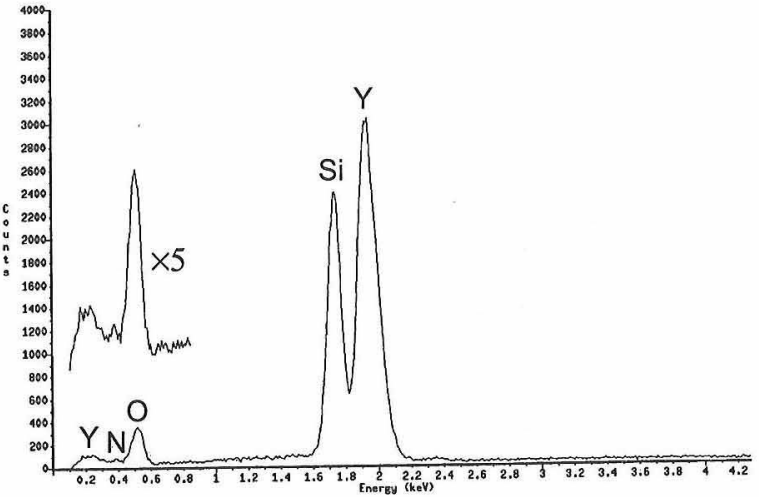

Fig. 6. Representative EDX spectra of (a) $\beta-\mathrm{Si}_{3} \mathrm{~N}_{4}$ grain, (b) the grain boundary glassy phase of the composition $(1: 2)$, and (c) that of the composition $(2: 1)$. means a significant concentration of nitrogen in the glassy phase of the composition $(2: 1)$. Thus, we conclude that the nitrogen solubility is higher in the liquid phase of the composition $(2: 1)$ than in that of the composition $(1: 2)$.

Dressler et al. ${ }^{11)}$ defined critical sizes $d_{\text {crit }}$ for $\alpha$ - and $\beta$ crystals below which they dissolve into the liquid phase at a given concentration, and suggested that some fine $\beta$ crystals could dissolve even with the existence of $\alpha$ crystals. It was also suggested that the critical sizes could be significantly influenced by the additive composition (a higher nitrogen solubility shifts $d_{\text {crit }}$ to higher values). ${ }^{12)}$ In general, the number of finer particles is much larger than that of larger particles in the raw $\mathrm{Si}_{3} \mathrm{~N}_{4}$ powder. As a result, the difference in the additive composition could cause a significant influence to the number and size distribution of $\beta$-crystals originally contained in the raw powder. Figure 7 compares width distributions of $\beta-\mathrm{Si}_{3} \mathrm{~N}_{4}$ crystals heattreated at $1750^{\circ} \mathrm{C}$ for $2 \mathrm{~h}$ with the $(1: 2)$ and $(2: 1)$ compositions. As already mentioned, XRD analysis shows that the phase transformation almost completes in this condition. Assuming that no homogeneous nucleation of $\beta$ crystal occurs, ${ }^{13)}$ and based on the experimental fact that width growth is negligible during the phase transformation, ${ }^{14)}$ width distributions shown in Fig. 7 are expected to be the size distributions of $\beta$-crystals that has been determined when the initial dissolution of $\mathrm{Si}_{3} \mathrm{~N}_{4}$ into the liquid phase has completed to reach the equilibrium. As expected, a significant difference in size distribution is observed between two compositions. Fine particles with a size less than $0.8 \mu \mathrm{m}$ that show the largest frequency in the $(1: 2)$ composition is found to be almost disappeared in the $(2: 1)$ composition. To analyze how much $\beta$-crystals were dissolved in the initial liquid forming stage, $\beta$-particle densities (number $/ \mathrm{m}^{3}$ ) were calculated for both the raw powder and the powders heat-treated at $1750^{\circ} \mathrm{C}$ for $2 \mathrm{~h}$. The $\beta$-phase content in the raw $\mathrm{Si}_{3} \mathrm{~N}_{4}$ powder is about $3 \%$. Assuming that the mean particle size of the $\beta$-crystals is identical to that of the raw powder, the $\beta$-particle density in the raw powder can be calculated from its specific surface area value of $5 \mathrm{~m}^{2} / \mathrm{g}$ to be about $1.1 \times 10^{18} / \mathrm{m}^{3}$. Using the mean width and length of the powder heat-treated at $1750^{\circ} \mathrm{C}$ for $2 \mathrm{~h}$, a $\beta$-particle density can be calculated for each composition; about $8.3 \times 10^{17} / \mathrm{m}^{3}$ and $5.6 \times 10^{16} / \mathrm{m}^{3}$ for $(1: 2)$ and $(2: 1)$, respectively. This suggests that the dissolution of $\beta$-nuclei is very small in the $(1: 2)$ composition, while the number of $\beta$-nuclei decreases to about $1 / 20$ in the $(2: 1)$ composition due to its larger solubility. This

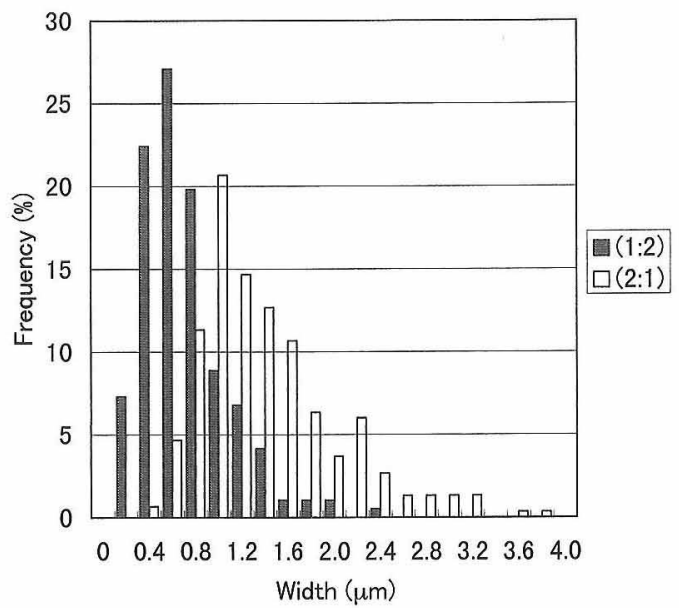

Fig. 7. Width distributions of $\beta-\mathrm{Si}_{3} \mathrm{~N}_{4}$ crystals heat-treated at $1750^{\circ} \mathrm{C}$ for $2 \mathrm{~h}$ with the additive compositions of $\mathrm{Y}_{2} \mathrm{O}_{3}: \mathrm{SiO}_{2}=1: 2$ $(1: 2)$ and $\mathrm{Y}_{2} \mathrm{O}_{3}: \mathrm{SiO}_{2}=2: 1(2: 1)$. 
difference in the number of $\beta$-nuclei leads to a significant difference in aspect ratio at the completion of the $\alpha-\beta$ transformation as predicted by the model. ${ }^{8)}$

A next fundamental question is why the solubility of $\mathrm{Si}_{3} \mathrm{~N}_{4}$ increases with the increase of the $\mathrm{Y}_{2} \mathrm{O}_{3} / \mathrm{SiO}_{2}$ ratio. Lamercier et al. concluded that yttrium ion was a network modifier in the oxynitride glass. ${ }^{15)}$ Ellison and Hess pointed out in their study of $\mathrm{K}_{2} \mathrm{O}-\mathrm{SiO}_{2}-\mathrm{R}_{2} \mathrm{O}_{3}(\mathrm{R}=\mathrm{La}, \mathrm{Gd}, \mathrm{Yb})$ system that equilibrium phases in the phase diagram were not necessarily representative constituents in the liquid phase, and that the liquid phase containing silica mainly consisted of Si-O network. ${ }^{16)}$ Assuming that an yttrium ion behaves like lanthanide ions in silicate glass and is primarily a network modifier so that it exists out of the $\mathrm{Si}-(\mathrm{O}, \mathrm{N})$ network structures, electric neutrality requires more nitrogen dissolution with the increase of yttrium ion to increase the number of negative valence of silicate chain. Based on this idea, Fig. 8 illustrates the relationship between the yttrium/silicon atomic ratio ( $\mathrm{Y} / \mathrm{Si}$ ratio) of the liquid phase and the nitrogen/oxygen atomic ratio (N/O ratio) for various glass structures. The notations, neso, soro, ino and phyllo, denote mono-silicate $\left(\mathrm{SiO}_{4-x} \mathrm{~N}_{x}\right)^{(4+x)-}$, disilicate $\left(\mathrm{Si}_{2} \mathrm{O}_{7-x} \mathrm{~N}_{x}\right)^{(6+x)-}$, chain $\left(\mathrm{SiO}_{3-x} \mathrm{~N}_{x}\right)^{(2+x)-}$ and sheet $\left(\mathrm{Si}_{2} \mathrm{O}_{5-x} \mathrm{~N}_{x}\right){ }^{(2+x)-}$ structures, respectively. In all structures, nitrogen solubilities steeply increase to reach their saturation with the increase of the $\mathrm{Y} / \mathrm{Si}$ ratio. It was also reported that the amount of non-bridging oxygen (NBO) increased as the amount of lanthanide ion increases. ${ }^{15)}$ This implies that the network structure gradually shifts from relatively tight structures like sheet and chain (low nitrogen solubility) to relatively loose structures like disilicate and mono-silicate (high nitrogen solubility) as the $\mathrm{Y} / \mathrm{Si}$ ratio increases. As a result, it is expected that the nitrogen solubility would gradually increase with the increase of the $\mathrm{Y} / \mathrm{Si}$ ratio changing the glass structure.

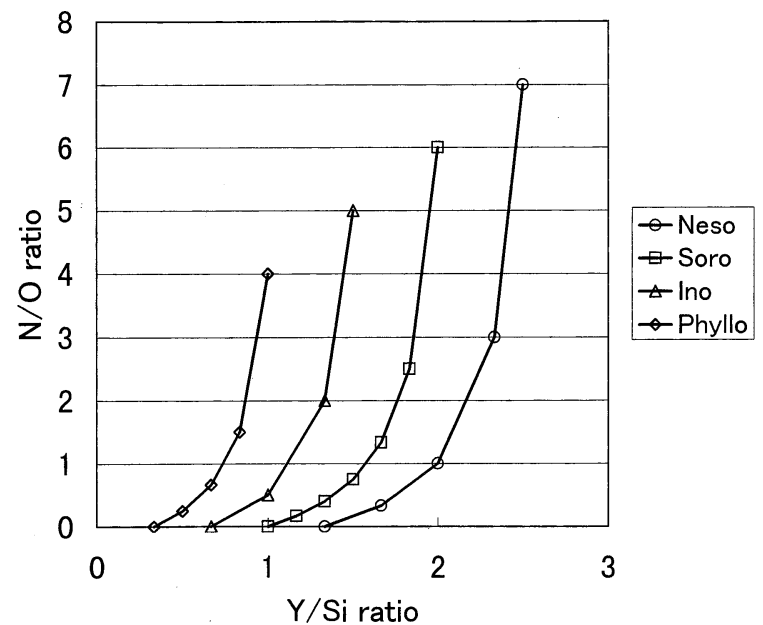

Fig. 8. Effect of $\mathrm{Y} / \mathrm{Si}$ ratio on the solubility of nitrogen (N/O ratio) in the $\mathrm{Y}-\mathrm{Si}-\mathrm{O}-\mathrm{N}$ glass with various silicate structures: neso, soro, ino and phyllo denote mono-silicate $\left(\mathrm{SiO}_{4-x} \mathrm{~N}_{x}\right)(4+x)-$, disilicate $\left(\mathrm{Si}_{2} \mathrm{O}_{7-x} \mathrm{~N}_{x}\right)^{(6+x)-}$, chain $\left(\mathrm{SiO}_{3-x} \mathrm{~N}_{x}\right)^{(2+x)-}$ and sheet $\left(\mathrm{Si}_{2} \mathrm{O}_{5-x} \mathrm{~N}_{x}\right)^{(2+x)}-$ structures, respectively.

\section{Conclusion}

The "seed" fabrication process has been used for systematically investigating the effect of $\mathrm{Y}_{2} \mathrm{O}_{3}$ and $\mathrm{SiO}_{2}$ ratio on grain growth of $\mathrm{Si}_{3} \mathrm{~N}_{4}$. The aspect ratio of $\beta-\mathrm{Si}_{3} \mathrm{~N}_{4}$ crystals heat-treated with an additive composition of $\mathrm{Y}_{2} \mathrm{O}_{3}$ : $\mathrm{SiO}_{2}=1: 2$ has been found to be much smaller than that of $\mathrm{Y}_{2} \mathrm{O}_{3}: \mathrm{SiO}_{2}=2: 1$. It has been confirmed that this is due to the difference in solubility of $\mathrm{Si}_{3} \mathrm{~N}_{4}$ by changing the $\mathrm{Y}_{2} \mathrm{O}_{3} /$ $\mathrm{SiO}_{2}$ ratio of the liquid phase. The number of $\beta$-crystals originally contained in the raw $\mathrm{Si}_{3} \mathrm{~N}_{4}$ powder changes very little in the $\mathrm{Y}_{2} \mathrm{O}_{3}: \mathrm{SiO}_{2}=1: 2$ composition, however, it significantly decreases in the $\mathrm{Y}_{2} \mathrm{O}_{3}: \mathrm{SiO}_{2}=2: 1$ composition, which results in a considerable difference in aspect ratio of $\beta-\mathrm{Si}_{3} \mathrm{~N}_{4}$ crystals. The enhanced solubility of $\mathrm{Si}_{3} \mathrm{~N}_{4}$ in the liquid phase with high $\mathrm{Y}_{2} \mathrm{O}_{3} / \mathrm{SiO}_{2}$ ratio could be explained based on the assumption that yttrium ion is primarily a network modifier in the $\mathrm{Y}-\mathrm{Si}-\mathrm{O}-\mathrm{N}$ glass.

Acknowledgement This work has been carried out as part of the Synergy Ceramics Project under the Industrial Science and Technology Frontier (ISTF) Program promoted by AIST, MITI, Japan. Under this program, part of the work has been funded through the New Energy and Industrial Technology Development Organization (NEDO). The authors are members of the Joint Research Consortium of Synergy Ceramics.

\section{References}

1) K. Hirao, T. Nagaoka, M. E. Brito and S. Kanzaki, J. Am. Ceram. Soc., 77, 1857-62 (1994).

2) K. Hirao, K. Watari, M. E. Brito, M. Toriyama and S. Kanzaki, J. Am. Ceram. Soc., 79, 2485-88 (1996).

3) K. Hirao, A. Tsuge, M. E. Brito and S. Kanzaki, J. Ceram. Soc. Japan, 101, 1078-80 (1993).

4) S. Kanzaki, O. Abe, T. Nagaoka and Y. Nakajima, Proc. of the 2nd Int. Conf. on Ceramic Powder Processing, Berchtesgaden, Germany (1988) pp. 739-46.

5) H. Park, H.-E. Kim and K. Niihara, J. Am. Ceram. Soc., 80, 750-56 (1997)

6) W.-H. Lee, H.-E. Kim and S.-J. Cho, J. Am. Ceram. Soc., 80, 2737-40 (1997).

7) M. Kitayama, K. Hirao, M. Toriyama and S. Kanzaki, Acta Mater., 46, 6541-50 (1998).

8) M. Kitayama, K. Hirao, M. Toriyama and S. Kanzaki, Acta Mater., 46, 6551-57 (1998).

9) M. Kitayama, K. Hirao, M. Toriyama and S. Kanzaki, J. Am. Ceram. Soc., 82, 2931-33 (1999).

10) L. Kaufmann, F. Hayes and D. Birnie, Calphad., 5, 163 (1981).

11) W. Dressler, H.-J. Kleebe, M. J. Hoffmann, M. Rühle and G. Petzow, J. Eur. Ceram. Soc., 16, 3-14 (1996).

12) M. J. Hoffman, "Tailoring of Mechanical Properties of $\mathrm{Si}_{3} \mathrm{~N}_{4}$ Ceramics," Ed. by M. J. Hoffman and G. Petzow, Kluwer Academic Publishers, Dordrecht, The Netherlands (1994) pp. 59-72.

13) G. Petzow and M. J. Hoffmann, "Grain Growth Studies in $\mathrm{Si}_{3}$ $\mathrm{N}_{4}$-Ceramics," Materials Science Forum, Trans Tech Pub., Switzerland, 113-115 (1993) pp. 91-102.

14) M. Krämer, M. J. Hoffmann and G. Petzow, J. Am. Ceram. Soc., 76, 2778-84 (1993).

15) H. Lemercier, T. Rouxel, D. Fargeot, J.-L. Besson and B. Piriou, J. Non-Cryst. Solids, 201, 128-45 (1996).

16) A. J. G. Ellison and P. C. Hess, J. Geophys. Res., 95 [B10], 15717-26 (1990). 